\title{
Evolution and Assessment of South Asian Folk Music: A Study of Social and Religious Perspective
}

\author{
Ruksana Karim* \\ Department of Music, Faculty of Arts, Jagannath University, Dhaka, Bangladesh. \\ *Correspondence: rukhsanakanon@gmail.com (Ruksana Karim, Lecturer, Department of Music, Jagannath University, \\ Dhaka, Bangladesh)
}

\begin{abstract}
This paper describes how South Asian folk music figured out from the ancient era and people discovered its individual form after ages. South Asia has too many colorful nations and they owned different culture from the very beginning. Folk music is like a treasure of South Asian culture. According to history, South Asian people established themselves here as a nation (Arya) before five thousand years from today and started to live with native people. So a perfect mixture of two ancient nations and their culture produced a new South Asia. This paper explores the massive changes that happened to South Asian folk music which creates several ways to correspond to their root and how they are different from each other. After many natural disasters and political changes, South Asian people faced many socio-economic conditions but there was the only way to share their feelings. They articulated their sorrows, happiness, wishes, prayers, and love with music, celebrated social and religious festivals all the way through music. As a result, bunches of folk music are being created with different lyric and tune in every corner of South Asia.
\end{abstract}

Keywords: Culture, South Asian folk music, Community, Tradition, Heritage, Rural, Evolution, and Lyric.

\section{INTRODUCTION:}

Since ancient era the development of art and culture is going on. Folk music is known as the fundamental element of art and culture. Our planet is roaming with 195 different nations whose are strongly connected by music (Albert, 1999). Though they have many types of languages, religions, foods, lifestyles but they are almost common in arts. Folk music is that form of art which was grown up since every nation's establishment. Famous musicologist Dr. Chaitannya D. Ranade has defined folk music as - "The music of people, by people and for people is folk music" (Chaitannya, 2012) Asia is the biggest continent with over population and South Asia is different in various

UniversePG I www.universepg.com cultures. Music is known as a most ancient art here. After ages, south Asian folk music has been changed in many ways and spread its branches. Mainly the structural changes of folk music happened by the evolution of language. Then individual musical tunes raised and people living with a separated community made various styles of folk songs. It has evolutes with people's taste, transmitted orally. So, this can be very difficult to find out the original composer of every folk song (Hossain, 2020). But history briefs that it composed by ordinary people followed by their tradition. Music is very close to their life cycle, most of them are a part of rituals. From the ancient period south Asia suffered many geographic and political changes near about thousand times. For that reason 
folk music moved here and there with people and settled after their independency (Saha, 2020). But between those periods, a huge customization has been created by the folk people to separate themselves from the others. As a result, we have revealed more over hundred patterns of religious songs, marriage songs, love songs, sad songs, festival songs, classical songs, boat songs, harvest cutting songs, season songs, separation songs and sufi songs in every rural areas of whole south Asia. After $20^{\text {th }}$ century, it becomes a developed urban civilization and the world recognized their folk music as an incredible heritage. The purpose of this study is to find out the reasons for the survival of primitive folk songs among sophisticated music like pop, rock DJ, hip-hop etc and discuss social-religious connectivity.

\section{Background of the Research}

South Asian literature and music can be explained by some book like Charyapad; an ancient Buddhist "Punthi" (a thousand years old book - written on palm leaf from Nepal) and Natyashastra by Varat Muni (India), Dastan-e-Amir Hamza (Pakistan), Sangam (Sri Lanka). Bangladesh, India, Pakistan, Afghanistan, Bhutan, Nepal, Maldives and Sri Lanka - these eight countries are known as South Asia together (Hiromi, 2012). But they are very different in culture and each country contains variety types of folk music. All of the folk songs have own structure, theme and composition. Though they have different tastes, folk songs are made with their choices and that is an incredible evolution rising continuously in South Asia.

\section{Research Questions}

1. What is the main texture of folk music in South Asia?

2. How many types of folk music in South Asia?

3. Why people assumed own music in society?

4. Why folk music is extra ordinary in South Asian culture?

5. What types of changes happening to the South Asian culture in modern ages?

\section{RESEARCH METHODOLOGY:}

This research is a descriptive-qualitative research that includes historical study of folk music, data collection and analysis, listening ancient and modern folk music UniversePG I www.universepg.com of different part of South Asia, collecting photos and gathering information from rural South Asia.

\section{Review of Literature}

In this study it reviewed topic relevant literature, articles, e-journals, websites, research reports and other documents to accomplish the research topic.

History of south Asian music - In every rural part of south Asia, music is not just a form of entertainment. It is an important element in many activities of daily life there and not to be used commercially. We have found the first symbol of music after discovering Indus valley civilization of the $3^{\text {rd }}$ and $2^{\text {nd }}$ millennia BCE. This valley has two ancient cities, known to us 'Mohenjo-Daro' and 'Harappa'. Some symbols like bronze statue of a dancing girl, terracotta and pictographs on the seal, ancient musical instruments (flute, drum) proves that the first civilization of south Asia had a modern art and culture. They had been terminated by the arrival of 'Aryan' civilization. Aryan came from the northwest part of Asia. Their religious poetry and different types of hymns are composed by the bard-priest to the praise of God. These are called 'Vedic chant' and it is known 'Veda' together. There are four 'Veda's and this ancient religious poetry is the basement of Hindu religion in south Asia. According to Winternitz (a German scholar of Vedic literature), these gathas and samavadsukta's (conversational hymns) in Vedas were prototypes of later folk songs, ballads and was the root of further development of dramas (Chaitannya, 2012).

Besides, the epic poems 'Ramayana', 'Mahabharata' (also known as 'Puranas') and the famous sermon 'Shri Shri Bhagavad-Gita' are also example of Hinduism. The pure ancient art of south Asia was identified after we found 'Natya-shastra'. It is a book of the explanation of drama accompanied dance and music which was written by 'Bharata'. Same time in the east part of south Asia, an ancient 'Punthi' (tale) was written and composed by some Buddhist poets. These are known 'Charyapod' together and it has different language- ancient Bengali language. Mainly these ancient books are the foundation of south Asian music and after much development it classified by two parts- classical music and folk music. There are also 
many antique literatures and rural theatrical songs (ballad, tale) that modified folk songs at early ages. That's the reason of a little bit changes between the music of south Asian countries. Richard M. Dorson has outlined four broad sectors of Folklore and Folk life studies; they are:

1) Oral Literature

2) Material Culture

3) Social Folk Customs

4) Performing Arts (Richard, 1972)

\section{Classification of folk music (region- south Asia)}

The configuration of south Asian folk music depends on its geographical effects, living styles and socioeconomic challenges. The weather of this area, their society-religion and their imaginative habits constantly influenced them to compose music. According to this side, it can be classified by 3 cycles - life cycle, socio-economic cycle and religious cycle.

Life cycle - this category consisting birth, marriage and death. Birth is the very common and happiest matter of our life. South Asian people have a tradition to welcome the new born baby like the others. On the other hand, death is the most mournful matter in world. There are no specific songs for birth and death in south Asia. But about marriage, they have a lot of traditional songs. Before wedding, especially in Bangladesh, India and Pakistan they celebrate haldi (turmeric) and mehendi (henna) ceremony (Marian, 2004). The famous songs of this event are -

Holud bato mendi bato, bato fuler mou

Biyar sajon sajbe konna, koromcha rong bou re

(Composer - Ali Hossain)

Origin - Bangladesh (movie - Dak babu) (Ruksana,

2017)

Language - Bengali

Meaning - smash turmeric smash henna, smash the honey of flower. The bride will glow after getting ready for wedding.

Lilabali lilabali vor juboti soi go

Ki diya sajaimu tore. (Composer - unknown)

Origin - Bangladesh

Language - Bengali

Meaning - lilabali lilabali the bride is too young.

Which material I use to decorate you?

UniversePG I www.universepg.com
Babul ki duaayein leti ja

Ja tujhko sukhi sangsar mile (composer - Ravi

Shankar Sharma)

Origin - India (movie-Neel Komal)

Language - Hindi

Meaning- take blessings from your father, I wish you have a happy married life.

Mehendi lagake rakhna, doli sajake rakhna

Le ne tujhe o gori, ayenge tere sajna (composer - Jatin lalit)

Origin-India (movie - Dilwale Dulhaniya le Jayenge)

Language - Hindi

Meaning - apply henna and decorate a cart. Your

husband will to lift up you.

Chitta kukkad banere te,

kashni dupatte vaaliye

Mundasadke tere te (Composer - unknown)

Origin - Pakistan (Panjabi folk song)

Language - Panjabi

Mangala nakathin yannata, suba welawa lunwiya diyani

Ape sewana hara apata noridawa, oba apagen samuganne

Suba gananak wewa sudu duwa, suba gamanak wewa.

(Composer - unknown)

Origin - Sri Lanka

Language - Sinhala

Hitru badline cha,phool haru phool ne cha

Feri jharcha ti sabai, hamro maya rahancha

Sukha hos ya dukha,nirogi hos ya rogi

Jahile sath dine chu, hamro maya rahancha.

(Composer - selah)

In qafelaye omar ajab megozarad

Ahesta boro, mahe man ahesta bero (Composer unknown)

Origin - Afghanistan

Language - Persian

Meaning - walks slowly (This is the traditional entry song of Afghan bride and groom)

Generally the senior person of family and society (grandmother, aunt) and young girls (sister in laws, cousins and friends of bride and groom) were used to perform these types of wedding songs in $19^{\text {th }}$ century. 
They used various traditional instruments like dolok, flute, sehnai and performed chorus with claps. In $20^{\text {th }}$ century in advance of electronic technology, wedding songs were played through cassette, $\mathrm{CD}$ and speaker. Boys were started to participate with girls in wedding functions. In the middle of $20^{\text {th }}$ century, wedding celebrations became very popular in society and an unexpected competition of luxurious wedding party began. Now a day's wedding songs are performed with dance, live music and DJ party is a mandatory part of wedding celebration. Even bride and groom both perform together with their mates. Native folk songs are performed with DJ and heavy metal instruments. Sometimes Bollywood songs are played instead of folk music.

Socio-economic cycle - Folk music is very close to this cycle. From the ancient period, south Asia had a civilized nation. Most of the people were farmer in the beginning. By the renovation of civilization people started to change their occupation for better life. As a result their economy grew up and we found much social discrimination between rich and poor. Rich people were a very few in number, but most of the general people were poor and they had no entertainment. Most of them were boatman, fisherman, snake-charmer, weaver, blacksmith, potter, coachman, teacher, saint, herdsman, wood-cutter etc. Their lifestyle, sorrows and happiness were taken placed in their music and that's the way they share their feelings with others.

In Bengali music history the ancient book 'Charyapad' represents the traditional literature and music practice in Bangladesh. After 'Charyapad' many antic book likes 'Geeta-govinda', 'Nath-geetika', 'Srikrishna kirtan', 'Monosa- mangal' also described the continuous musical movement in few centuries. Bengali folk music mainly inspired by these books (Chakraborty, 2011). During the British period, Bengali rural community became converting to urban. In this time, folk music was started to get popularity and composed by some educated urban people. Ramprasad, Komolakant, Ramnidhi gupta, Kalimirza, Shridhar kathak, Dashorathi roy, Govinda adhikari, Gopal ure, Madhukan, Girishchandra ghosh were the respected folk song writer in the first half of British period (Chakraborty, 2011).

UniversePG I www.universepg.com
They had introduced Bengali music with a new pattern and folk song became simplified. By following them, composing music was a famous profession to the new generation. Tagore family was the example of that time. Most of the young men of this family were like to compose music. Jyotirindranath Tagore, Rabindranath Tagore, Dijendra lal roy, Kazi nazrul islam, Atul Prasad sen, Rajanikant sen, Lalon fakir, Radharaman datt, Hason raja, Ramesh shil were the most popular music creator of Bangladesh (Prabhat, 2005). Before the arrival of technology in south Asia, the entertainment in the rural areas depended on a large coverage of stage performances by folk singers. The rural folk music can be classified in numerous sub genres like -

a) Lalon - This is the most popular folk music, written and composed by Lalon Fakir of Kushtia, Bangladesh. His spiritual composition and unique style is liked by the rural and urban generation both. These songs are very popular in abroad also. Example -

Dhonnyo dhonnyo boli tare

Bedheche emono ghor

Shunnyer upor posta kore.

Meaning - hails that Almighty, who has created the world on vacuity.

b) Bhatiali - This is a kind of music that always composed by a common raga (mode) and sung by fisherman or boatman. Bangladesh is a land of river and a good number of rural people lives by catching fish. They have to spend near about six months on boat and they compose songs to avoid loneliness. Generally this type of song has a long tune emphasized by water and the lyric focused the desire to go back home. Example -

Koi jao re, Padmar dheu amar kotha loiya jao re Andhar raite majh doriyay, baite achi nao re Meaning - where are you going river Padma? Please take my speech. It is dark night and I am sailing in middle of river.

c) Bhawaiya - These songs are written and composed by bullock-cart driver in north part of Bangladesh. The dry weather and long passage from home is the main theme of its lyric and tune is as long as the roads, sometimes bumpy like the rough channel. Example - 
Baokumta batas jemon, ghuriya ghuriya more

$\mathrm{O}$ ki o re tor moton mor garir chaka ponthe

Ponthe ghure re o ki gariyal mui choron rajo ponthe.

d) Gambhira - Gambhira is a very famous song of Chapai-nawabganj, Bangladesh performed with a particular distinctive rhythm and dance. It has always two performers, acting the character of grandfather and grandson for social awareness. Example -

Hey, nana. bose thakis na ar ghore te

Nana chol jai brikkhoropon korite

Meaning - hey, grandpa don't be seated inside

home. Let's go, plant some trees.

e) Dhamail - A dance oriented folk song of the east part of Bangladesh. It is practiced in Sylhet, Bangladesh and in areas influenced by the sylheti culture such as Shilong, Assam \& Tripura in India. Example -

tomra kunjo sajao go, aij amar pranonath asite pare Mone chay prane chay, dile chay jare.

Meaning - friends please decorate the garden, today my lover can come. My heart and soul wants him.

f) Hason raja- another popular song of Sylhet zone, written and composed by land lord Hason raja. It has one of the most devotional lyric and very rhythmic tunes. He also composed spiritual songs like Lalon fakir. Example -

Loke bole, bole re ghor bari vala na amar

Ki ghor banaimu ami shunnyeri majhar.

Meaning - people say that my house isn't good. Which type of house I would make in this emptiness?

Besides these songs, there are Jhumur, Baul, Sari, Zatra, Zarigan, Kavigan, Palagan, Bhandari and tribal songs too. Bangladesh has also a good number of patriotic songs and film songs inspired by folk songs. It is notable that the national anthem of Bangladesh was composed by Rabindranath Tagore following a famous baul song 'ami kothay pabo tare'. Abbas uddin ahmed, Abdul alim, Nina hamid, Ferdousi begum, Baul Shah Abdul karim, Fakir Majnu shah, Rathindranath roy, Pilu mamtaj, Kuddus boyati, Fakir Alamgir, Kangalini Sufiya, Kiran Chandra roy, Chandana Majumder, Farida pervin, Bari siddiqi, Momtaj begum, Shyam sundar vaisnab, Saidur rahman boyati, Indramohan rajbangshi are the famous folk singers in Bangladesh.

UniversePG I www.universepg.com
Folk music is closely associated with farming and other such professions and evolved to alleviate the hardship and break the monotony of the routine life. (Cultural India, 2020) In India, the folk music is almost same as Bangladesh in tune, but they have different language and rhythm. India is one of the biggest countries of Asia and almost every region in India has its own folk music. As early as $400 \mathrm{BC}$, Indian musical treatises had drawn a clear distinction between marga sangeet (music for the gods) and desi sangeet (music of people) and it is the latter that evolved into what we now know as folk music. The Indian subcontinent is a huge and diverse area with hundreds of different languages and dialects, and folk music varies greatly from region to region (Jameela, 2011).

Now a day, Marga sangeet is known as classical music. The modern Indian classical music has two parts- Hidustani and Karnataki. But the folk music has many forms including Dandiya, Bhangra, Jugni, Sufi, Lavani, Garba, Bhavageete, Naatupura padalgal, Bihusong, Kajri, Chaiti, Rasiya, Pandavani, Uttarakhandi, Veeragase, Kolattam, Tamang selo, Baul song, Vatiali, etc. Here some songs are given below that introduces traditional folk music of India -

i) Bihugeet - Bihugeet is known as a very popular Assamese traditional folk song. This kind of song is generally associated with the Bihu dance which is performed by a group of young men and women. They dance with the beats, holding each other and they looks very beautiful with traditional dress. Example -

Bihur e logon modhur e logon

Akashe batase lagilo re

Chompa futiche chameli futiche

Tar subase moyna amar vasilo re.

ii) Naatupura paatu- Naatupura paatu is a traditional folk song of Tamil Nadu, but also played in Rajasthan, India. These songs are usually accompanied by traditional drums and sehnai. Sometimes traditional dance performance also accompanied with them. Example -

Nattupura paatu onnu

Naan padikkiren kelu machaan

Nattupura paatu onnu

Naan padikkiren kelu machaan. 
iii) Kajri - This is a traditional folk song with classical motif, originated in Bihar, India. This type of song is known to be gloomy and loneliness, sung by women. During monsoon when their husband has been away from home, kajri song accompanied them to enjoy the loneliness. This song had been composed in particular ragas and this song is classified in semi-classical genre in modern ages. Example -

Mag bichkare bar jori ram

Sham salone sawariya

iv) Maand - This is a traditional folk singing style of Rajasthan and also known as semi-classical music. This song has the soulful music with its expressive scales of sarengi and the lyric tells about the life. Example -

Kesariyan, balma more

Badharo mere desh.

v) Koli - Traditional song of fisherman and very fast beat, dance oriented composition. This is the song originated in Maharastra, India. The lyric of this song talks about the life at sea and the composition associated with their unique dance style. Example -

Ayi tujh deul, sajatyi gulalle dongran gi

Gulalle dongran palkita nachin

Gulal urvun shetache mahinan gi

Setache mahinan.

vi) Lavani - Lavani songs are often used in theatrical performance with erotic or socio-politically charged lyrics. These songs are usually sung by women and used a lot of classical ingredient in folk pattern. Example -

Latpat latpat latpat latpat

Tujha chalnag motha naghra char

Chanag motha naghra char

Bolnag manjhra me ni char.

vii) Baul music - Indian boul songs are found in west Bengal which is very close to Bangladeshi baul songs. They used traditional instrument ektara, dotara and dubki. These songs are influenced by Buddhism, Sufism and Bengali Vaisnaism also. Baul song is the most antic musical art of south Asia and very close to native people. Example -

Sona bondhu tui amare korli re diwana

Mone toh mane nah, dile toh bojhe nah. UniversePG I www.universepg.com viii) Garba - Garba is a traditional dance related folk music especially played to celebrate 'Nabaratri' in Gujarat, India. Garba songs typically revolve around the subjects of Lord Krishna or the nine goddesses. The word Garba comes from the Sanskrit word for womb and so implies gestation \& life.

Example -
Gori sharmayi, man mein muskayi
Gunji angina mein sehnai
Baje gali mein dhol, gori ghunghatiya khol
Pi se Milan ki ghari ayi

ix) Bhangra - Bhangra is a form of dance oriented folk music of Punjab, India and Pakistan during harvest season. Example -

Deshi jat nu bhilaiti daru chadh gai

$\mathrm{O}$ balle balle ni tere jiyan lakh vekhiyan

Folk music is also used for educational purposes. For instance sex education has traditionally been taught in Andhra Pradesh by song. There is a function when a girl has her first menses. In this function the elderly women in the community gather at the house (men are definitely excluded) the girl is given her first woni and langa (half sari which is worn by unmarried girls), rich food and other gifts. During this function the women sing songs that are extremely bawdy. To an outsider this would seem uncharacteristic of obviously respectable community members. However the function of such songs is to provide the girl's first instructions on her emerging womanhood and what her future marital duties will be (David, 2020). The famous folk singers who currently representing Indian folk music are - Mallika Pukhraj, Gambhari devi, Chinnaponnu, Malini awasthi, Bhikhari thakur, Kalika Prasad vattyacharya, Kamal heer, Zubeen garg, Illa arun, parvati baul, Kartik Chandra baul, Amar arshi, Allah jilai bai, Anima chowdhury, Anupama deshpande, Jagjit kour, Diller mehendi, Vimalakka, Usha utthoop, Thanjai selvi, Pratima barua pandey, Papon, Vijayalakshmi navaneethakrishnan, Mukhtiyer ali, Surinder kour, Jagmohan kour, etc (Jameela, 2019).

Sri Lankan folk music is a mixture of ancient Buddhist religious tradition and Indian native culture. The influence of both European colonization and African traditions served to further expand the musical roots of 
contemporary Sri Lankan music. In the mid of fifteenth century, the Portuguese were first arrived in Sri Lanka and brought traditional guitars, ukuleles, cantiga ballads. Before that the native people usually entertained themselves by folk poem 'Kavi'. Another traditional folk song is known as 'Virindu' and 'Baliya'. The famous country music of Sri Lanka is classified in some sub-genre like Kolam and Puppetry, Pageantry, Nurti, Sinhala light music etc. Here a famous traditional Sri Lankan folk songs is given below -
Adhare hithenawa dekkama
Dewangana wage lassanai
poddak inna sudo ma
enawa langatama den hondai

W.D Amaradeva, Lionel ranwala, Sunil santha, R.A Chandrasena, Niranjala sarojini are known as famous folk music artist. Most of the Nepali folk music is composed locally and sung in the fair, market, choutaries in every occations. Some notable traditional Nepali folk songs as Malashree tune played in Dashain, Asare Bhaka sang while planting rice, Sakela sang in Udhauli-Ubhauli, Deusi-Bhailo songs played in Tihar etc. these folk songs have their own origins and importance. Palam from Limbus, Syabru from Sherpas, Selo from Tamangs, Kaura from Magars, Hakpare from Eastern states makes Nepali tradition glorious including Deuda from Far-Western, Holi songs from Terai, Sakiyapaiya from Tharus, Newari songs, Teej songs equally. Example -

A) Eastern Folk Song - This is sung in eastern regions while doing household chores. Example -

\section{Himchuliko Hiu Ko Paani \\ Goganpaat Le Piula Hajur \\ Yeti Ramro Dhalke Jowan \\ Timilai Nai Diula Hajur.}

B) Tamang Selo - This is a traditional song of Tamang community who lived in hills in eastern and western part of Nepal. Specially used for expression of love, passion and sorrow, Tamang Selo is also sung as question \& answer between two competing groups of singers. (Kullabs). Example -

Ghorki Syauri Gyalmari

Gengla Tukra Supari

Geng Tukrata Syauri Se Dhuike Laji Chyago.
C) Hori Song - This is sung in eastern Terai regions, especially in Mithila areas during Holi festival. Example -
Mithilame Ram Khelat Hori Mithilame
Kinaka Ke Haath Kanak Pichkari
Kinaka Ke Haath Abir Jhori
Mithilame....
Ramji Ke Haath Kanaka Pichkari
Siyaji Ke Haath Abir Jhori
Mithilame.... Mithilame Ram....

D) Deuda Song - This is sung in far western Nepal during various festivals and occasions. Example -
Rai Jhuma Jhuma Kya Maskya Chhan Ho, Rai Jhuma
Chaubandi Dhakako Cholo, Chhitko Fariyaki
Paatali Ghar Kahan Ho Tamro Baisa Bhariyaki
Ma Ta Rai Jhuma, Jhuma Kya Maskya Ki Chha Ho, Rai Jhuma.

E) Palam Song - This is sung in eastern regions by Limbu community. Example -
Singhao Thungwe Kakma Faag
Minchhangen Aani Yammi Saag
Iksagen Khambek Aadhokhelle
Thingnamdat Sarak Aabokhelle.

F) Teej Song - Teej is a religious festival of Nepal and northern part of India. A song by Hindu females during Teej festival is known as Teej song. Example -

Teejko Bela Sabai Janchhan Maaita

Aafno Maaiti Muglaan Paari Chhaina Saaita.

Dhramaraj thapa, Kumar basant, Jhalak man gandharva, Gyanu rana, Udit narayan, Arun thapa, Bhagawan bhandari, Tara devi, Sunita dulal, Koili devi, Raju lama, Master Mistrasen Thapa Magar, Vishnu majhi, Navneet aditya waiba are the famous folk singer of Nepal. In south Asia Afghanistan, Pakistan and Bangladesh are known as Islamic country, but Afghanistan and Pakistan has a very conservative society. They are quite different than Bangladesh. In Afghanistan, they owned Islamic culture during the fifteenth century and produced Sufi style vocal and instrumental music. Kabul and Herat are two of the cities and areas which have great tradition of folk music in Afghanistan, folk song from the herat is 
known as 'Herati'. Their music has strong influences of Iran and India both. Their lyrics often depict upon texts following from classical Persian poetry.

G) Klasik - Classical traditional music of Afghanistan which is called Klasik is under influence of North Indian classical music. This is quite close to Indian and Pakistani classical. There are several genres: sung poetry especially ghazals, and also instrumental pieces naghmeh and ragas. The music is predominantly urban and has close historical links with India and Pakistan (Simon et al., 2000). Each ethnic group in Afghanistan has its own style of folk music, with its own sound. Regardless of where a song is from, it usually tells about honor, love, war and family. Sometimes the theme of love is disguised with reference to roses and nightingales. Many folk songs are based on epic poems and folktales (Erin, 2003) The folk dance called Attan is regarded as the national dance in Afghanistan from the Pashtun area. Example-

Manba dunbal-e dilam ba chashm khonbar amadam Arezo gom karda-am ba halat-e zar amadam

An important improvised folk song genre of the region is known as Chahar Baiti (four lines or quatrain). Although chahar baiti literally refers to "four lines," it actually refers to couplets comprised of four half-lines with the rhyme scheme AABA. These short poems are usually composed on the subject of love and sung one after another, often inspiring new compositions. Example -

Maqorban-e sar-e darwaza mesham

Sadayat meshnawom estada mesham

Sadayat meshnawom az dur o nazdiq

Ma misli ghumcha-ye gul taza mesham

Meaning - I sacrifice myself at your doorstop (When) I hear your voice, I stand (When) I hear your voice from far or near I become as fresh as a flower bud.

During Taliban period, music has been very restricted in Afghanistan but some notable folk artist keep representing their tradition and culture as well. Safdar tawakoli, Faiz karizi, Sakeeb hamdard, Rizwan munawar, Mangal are most renowned folk artist of Afghanistan. Folk songs of Pakistan include the traditional forms of Balochi, Pashto, Punjabi, Sindhi and other regional languages. These are truly motivated by

UniversePG I www.universepg.com
Sufi styles like Ghazal and Qawwali songs. They also have a huge collection of religious songs. Besides these, Pakistan is known as a valley of art with traditional music.

i) Qawwali - Qawwali as a musical form is closely linked with the Sufi tradition of Islam and the particular practices that Sufi scholars developed to achieve closeness to God. When Muslim Sufis came to India, the first thing which struck them was the important role which music played in the socioreligious life of the local inhabitants. They realized that music would help them to communicate with the people and attract their attention towards the tenets of Islam. 18 Ghazal is a structured form of love poetry, written in six to twenty-six paired lines. This poetry appealed to people of all classes (Aleen, 2018). It is generally Urdu language based and has a connection to the root of classical Arabic poetry also."Ghazal" is Arabic word which means "Talking to women". Example -

\section{Dard Badhkar Dil Ka Hadd Se Paar Ho Gaya Sitamgar Jeena Ab To Mera Dushwar Ho Gaya. Hai Shikayat Mujhe Ab Khud Se Itni Kyun Maine Kabhi Kisi Se Pyar Kiya? Gam-A-Alam Me Duba Rehta Hoon Is Kadar Dard Ka Ek Silsila Ab Dil Me Reh Gaya.}

Meaning - pain increased and crosses the heart; it has difficult for me to live as an oppressor. I have so many complaints now, why I have loved someone ever? I am overwhelmed with lost memories, a series of pain lingered in my heart.

ii) Shindhi kafi - Sindhi kafi is an indigenous musical form of Sindh. The word kafi, is of Ararbic origin, used in the sense of "final" or "enough" in the expression "Allah Kafi", which means, "God Almighty is Supreme". Thus the kafi is a devotional form of music composed in a particular form derived from a mixture of classical, semi-classical, and light music forms (specifically, the kheyel, tappa, thumri, and geet). The mystic poetry of the Sufi saints is usually sung in this mode. Example -

$\mathrm{Ku}$ tak pernah terfikir jatuh cinta pada dirimu

Tak pernah terfikir kau kan jadi yang terindah.

Meaning - what to do if you want to be 'cinta pada dirimu'? Take a look at each and every one of this. 
iii) Hindko music - Music from Hazara Division is sung in Hindko language and is generally performed in ether the 'Mahiyay' or 'Shaer' styles (Marian, 2004). Example -

chitey chaney di chandni

sargi diya tariya....

ho sargi diya tariya lo chaa dy

mera chala gumahiye o chaa dy.

iv) Pashto music - Pashto music is commonly found in the federally administrated tribal area, Khyber pakhtunkhwa and in Pakistan's major urban centers such as Karachi, Rawalpindu, Lahore, Sialkoat and Multan. Music genres include Thappa, Charbeta, Neemkai, Loba, Shaan and Badala (Aleen, 2018). Example -

Lare ka ghamona jinae

Lare ka, lare ka ghamona.

V) Jhumar - Jhumar or Jhoomar is the traditional Saraiki folk dance. It is a lively form of music and dance that originated in the Multan and Balochistan. It is slower and more rhythmic. The word "Jhumar" comes from Jhum/Jhoom, which means Swaying. The songs evoke a quality which reminds of swaying. Though the content of these songs is varied - they are usually loved with emotional songs too. The Jhumar is a dance of ecstasy. Jhumar is performed usually at the wedding ceremonies. It is a living demonstration of the happiness. The dance is mostly performed by the Balochi and Saraiki people of Southern Punjab (Reza). Example -

\section{Meko eho ta dasa \\ kewain jor aeh thasi \\ way meko eho ta dasa \\ kewain jor aeh thasi}

The famous folk singers of Pakistan are Arif Lohar, Reshma, Alom Lohar, Shaukat Ali, Allan Fakir, Sain Zahoor,Tufail Niazi, Nusrat Fateh Ali Khan, Malika Pukhraj, Zarina Balooch, Abida Parvin, Farida Khanam, Ghulam Ali, Iqbal Banu, Mai Bhagi, Pathanay Khan, Rahim Shah, Sanam Marvi, etc. The Maldives is a South Asian nation connecting 26 islands together, to be found in the Indian Ocean, southwest of Sri Lanka and India. The native inhabitants of Maldives embraced Islam during the $12^{\text {th }}$ century and built up neighborhood with African and Asian nations beside the coast. Their culture has influenced by these mainland neighbors, codifying the unique Maldives sound. Lava, which is the Maldivian term for singing, has many different roots and traditions.

H) Bodu buru - This iconic music, which also is known as Boduberu, means Big Drums (Bodu Beru). The music is made for dancing and dancers celebrate Bodu Beru by performing dance rooted in the traditions of the islands starting with a slow beat that's tempo heightens as the dancers react and leading into a crescendo of wired frenzied movements inspired by the unbridled pulse of the beats (Rudolfo, 2018). This traditional music is performed as a complementary entertainment in their religious and social occasions. Example -

Mai hoorekety thee

Nala rivethi haa Soora libifai vaa

Mai maluge zaarehgaa fenivaa.

I) Thaara - This is another traditional music that represents the ancient culture of Maldives as well as semi religious aspects. Thaara is performed by around 22 male musicians, seated in two rows facing one another, and accompanied by dancers. Performers wear white sarongs, which are big spans of fabric wrapped around the waist, with white shirts and greens scarves around their necks. The music also begins slowly before the tempo gradually increases into a climax of melody and rhythm (Rudolfo, 2018)

Religious cycle - The main religions in south Asia are Islam, Hinduism, Jainism, Buddhism, Sikhism, Christianity, etc. Now a day, Islam is the largest religion in south Asia (30.08\%), but Hinduism and Buddhism are the most ancient religion here. Music is also highly connected to religious cycle. In Muslim countries like Bangladesh, Pakistan, Afghanistan and some places of India Hamd, Naat, Qawwali songs, Ghazal, Zikr and Islamic Sufi songs are known as Islamic folk music. On the other hand Kirtan, Shyama sangeet, Vakti geet, Bhaisnav geet, Bhajan are famous for Hindu religion in south Asian countries like India, Bangladesh and Nepal. There are also some devotional songs for Christianity and Buddhist chant in Sri Lanka, Nepal and Bangladesh. Example - 
Nai holo ma boson vuson

Ei Eid e amar

Allah amar mathar mukut

Rosul holar har (Composer - Kazi Nazrul Islam)

Origin - Bangladesh

Meaning - though I have no clothes in this Eid, Allah is the crown of my head and Rosul (swt) is my necklace.

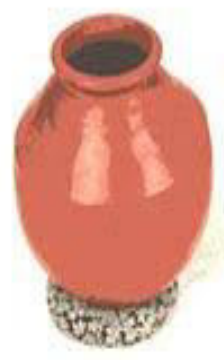

Fig 1: Ghatam

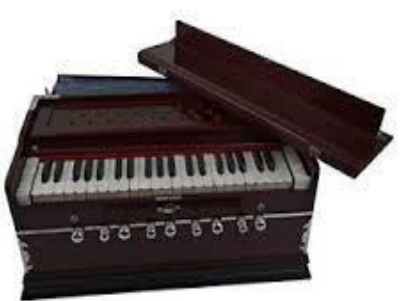

Fig 5: Harmonium

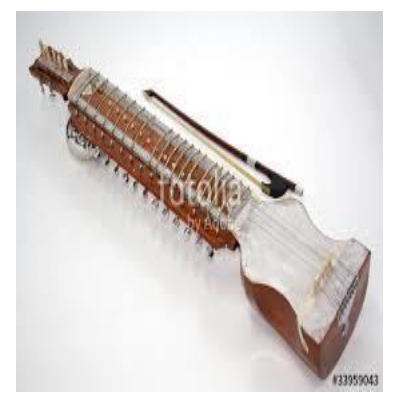

Fig 2: Dilruba

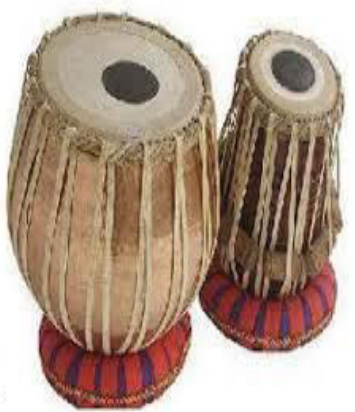

Fig 6: Tabla

Bochor bochor aste hobe tomay durga ma.

Meaning: you have to come every year, mother Durga.

\section{Traditional musical instruments}

There are various types of musical instrument used in south Asia. They are Dhol, Tabla, Flute, Harmonium, Dholok, Khanjani, Dotara, Ektara, Violin, Shankha, Sarengi, Mridangam, Rubab, Santoor, Sehnai, Damaru, Duff, Khamak, Karatala, Jhanjhar, Snake charmer veen, Chanda, Ghatam, Nagada, Tikara, Dilruba, Manjira etc.

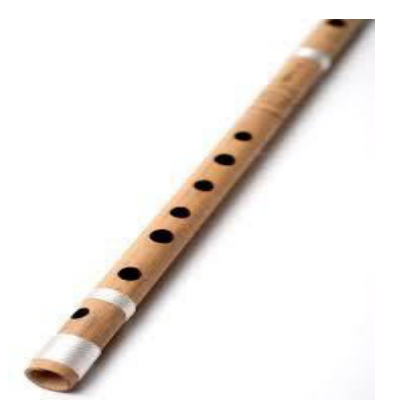

Fig 3: Flute

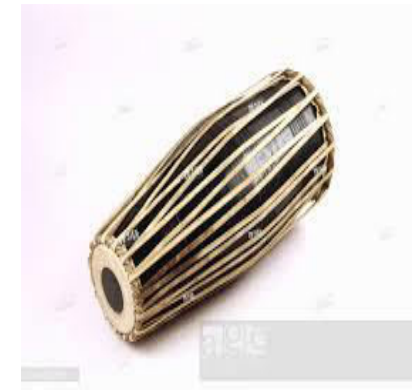

Fig 4: Mridangam

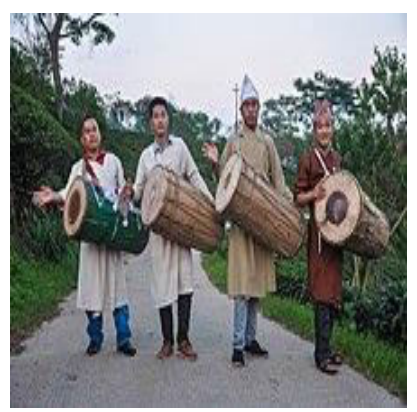

Fig 7: Chybrung

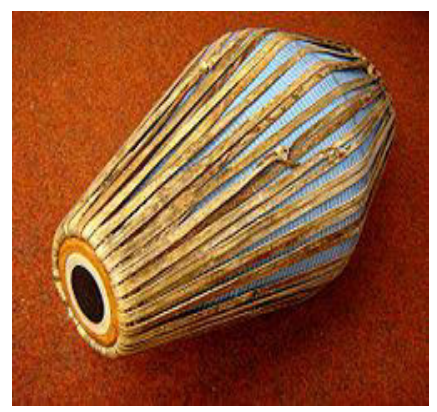

Fig 8: Khol

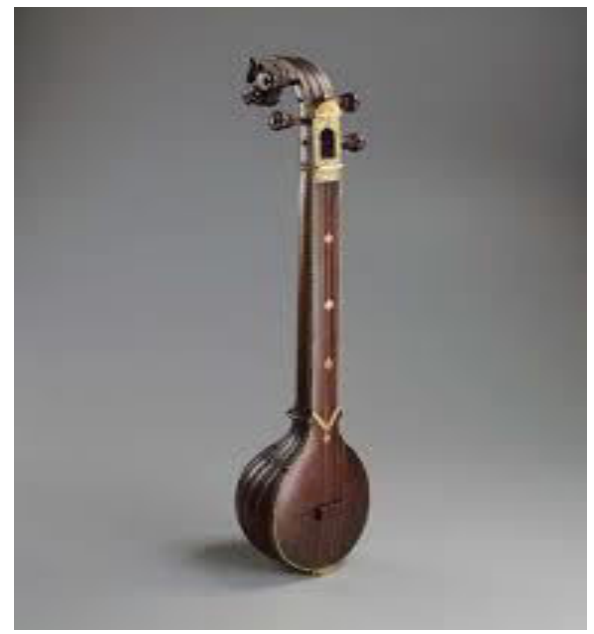

Fig 9: Tanpura

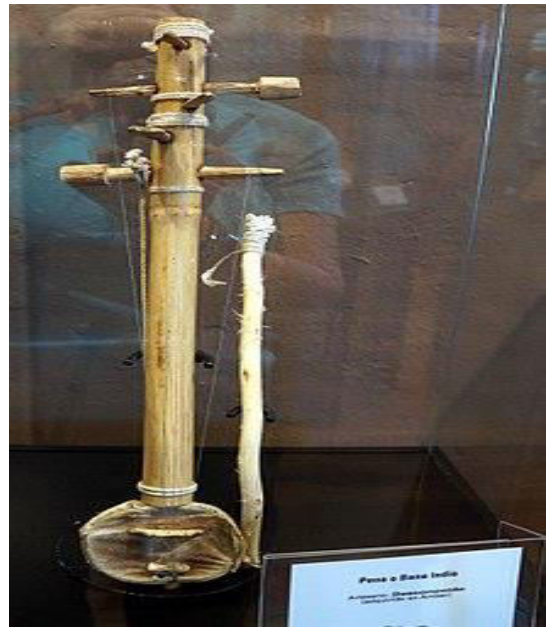

Fig 10: Ravanahatha

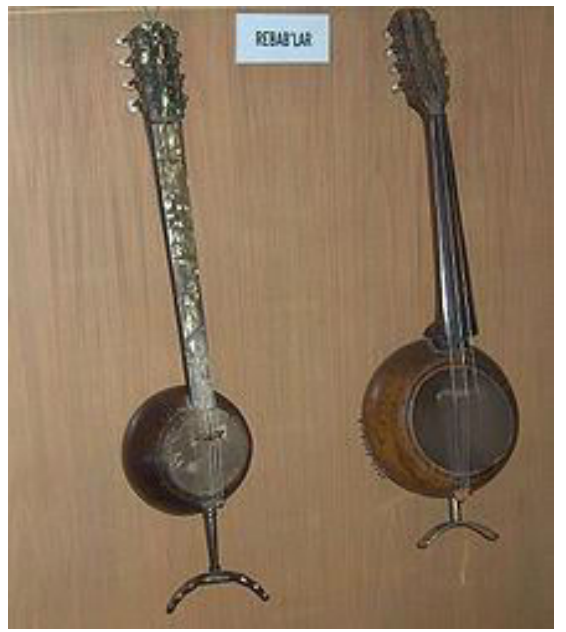

Fig 11: Rubab 


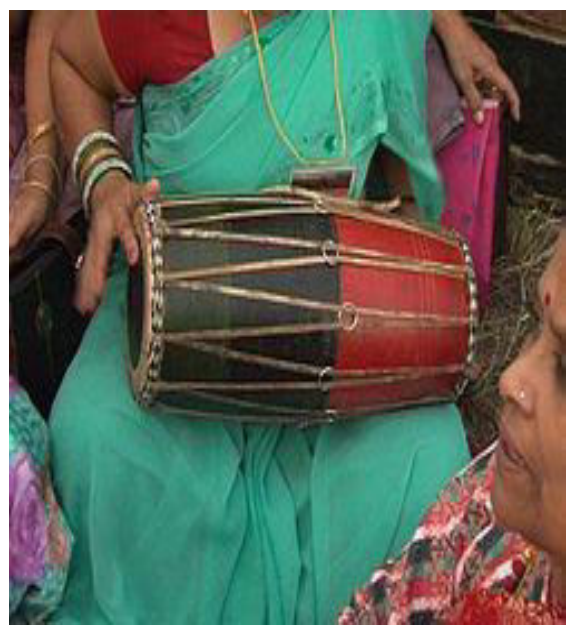

Fig 12: Madal

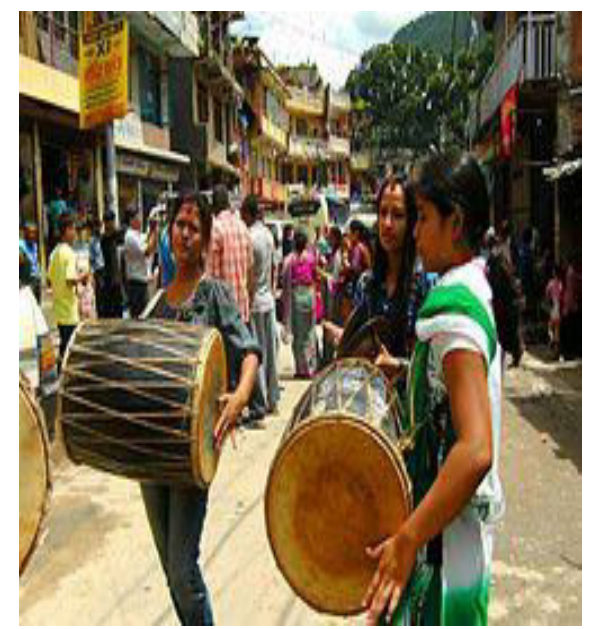

Fig 13: Dhimay

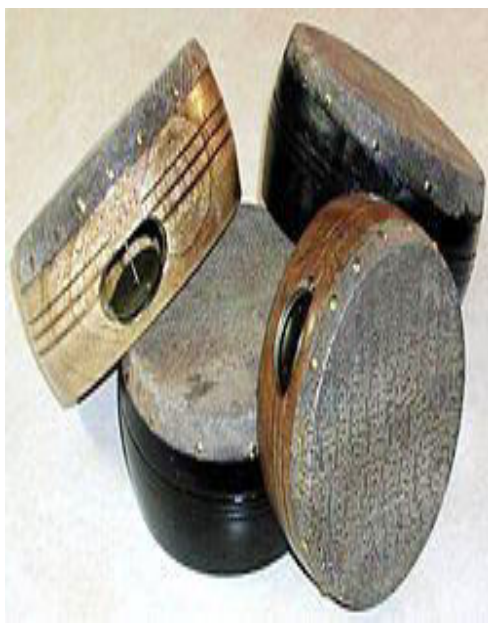

Fig 14: Kanjira

\section{Innovation of folk music in South Asia}

Folk music is recognized as a heritage in South Asia now a day. During British period, the people of this area were started to learn European culture and the local culture was getting improvised by urban people. They had to change their profession, life style, language, habit overall a complete transformation because the British government wanted to make them their follower. But the people didn't like that and they fought for liberation. After the independency South Asia becomes very decorative by conserving their individual folk culture and preserves the core of each nation. We should be very thankful to technology and the inventors of different media that helps us to record and broadcast music. Gramophones, Radio, Television, Cassette player, CD player, computer, Walkman, Mobile phone, iPods are the most popular media for music. At the last of $20^{\text {th }}$ century, Internet becomes the latest communicating media and getting popularity day by day. Now a day, folk music is highly recommended for identification. For example - international games like Olympic, World cup tournaments or in any reality/charity shows, all of the organizing countries represents their traditional folk music in opening and closing ceremony both. That is really the matter of pride and also prestigious.

After ages, the original composers of folk music were passed and they explored their music through the generation. In the megacities most of the music loving people has invented many electronic instruments using different technologies. These instruments are used with

UniversePG I www.universepg.com traditional instruments. Folk music is also sung with new compositions called 'Fusion' which is liked by our new generation. They often like to mix traditional folk songs with rock and pop music. So this is very encouraging that the original version of folk music with heavy metal instruments is getting popular day by day.

New generation is very much curious about leaning music and this advantage is the only way to exploring folk music globally. But some people doesn't like to mix or Fusion, even they aren't willing to use any band instruments with folk song. Actually they want to keep the purity of their music. Coke studio Pakistan took the first step by broadcasting these Fusions in south Asia. They had improvised their folk songs with a new composition and used highly professional electronic instruments to produce traditional tunes. They also made collage song with few lines taking from two or three different songs, used western patterns and that was a musical blast of the history of south Asian music. India also started this program followed by them and achieved highest popularity of all the television shows. Besides these, various types of folk song are uploaded by young folk artists in YouTube and social media also. The extreme uses of folk music are found in many movies, dramas and theatres of south Asia. The Indian movies like Laila-Majnu, Ali baba 40 chor, Lekin, Dor, Lagan, Swadesh, Mirza are based on Indian folklore and had a huge uses of folk music. They also have a good number of folk songs in their commercial cinemas. In Bangladesh, a lot of movies like- Behula, Rupvan, Suyorani-Duyorani, Sat 
vai champa, Nawab sirajuddoula, Nolok, Beder meye josna, Srabon megher din, Hason Raja, Moner manus are full of folk music. These two countries are very much sincere about their folk culture from the other countries of south Asia. Specially, Bangladesh became appreciated by the others after arranging "International Folk Fest" every year.

\section{CONCLUSION:}

Music's transformative reputation seems to be an ancient as discussions of music itself. Plato has Socrates remarks on this theme: "“And it is not for this reason Glaucon,' said I, 'that education in music is most sovereign, because more than anything else rhythm and harmony find their way to the inmost soul and take strongest hold upon it, bringing with them and imparting grace, if one is rightly trained and otherwise the contrary?" On this point Aristotle agrees with Plato: "It is plain that music has the power of producing a certain effect on the moral character of the soul, and if it has the power to do this, it is clear that the young must be directed to music and must be educated in it" (Albert, 1999). This is an age of globalization and south Asia becomes an incredible part of this. South Asian folk music has transformed in a new figure but still connected to the root. So this progression is not harmful, if the original material exists. Evolution is just a process to take forward with a combination of different tastes and folk music rising tremendously combining latest technologies and compositions. This study reviews various aspects of the life of the people of different parts of South Asia, including religious rituals, livelihoods, which are associated with music. It is a complete explanation of the internal thoughts of South Asian native people and only folk songs contains their poetry and melody. Pop, rock, DJ, hip-hop, rap music have only beats, not emotions. These songs can create excitement only but folk songs are able to create happiness. Folk music has all those quality which cannot be found in modern music. That's the reason of worthiness of folk music. It will be helpful for other research; related with South Asian folk music. In $21^{\text {st }}$ century, opportunities to exchange new musical ideas, as well as preserve traditional ones, provide south Asian folk artistes an indication to innovating new styles that reflect their contemporary world. So, we can say that south Asian UniversePG I www.universepg.com folk music turned into the international age of music through the thousand year's continuous evolution and achieved a glorious dignity.

\section{ACKNOWLEDGEMENT:}

This study was supported with proper help and guidance in the Dept. of music, Jagannath University, Bangladesh. Heartiest thanks to Dept. of history, Jagannath University, Bangladesh. All translations from Hindi, Urdu, Arabic, Pashto, Sindhi, and Bengali are mine unless otherwise stated.

\section{CONFLICT OF INTERESTS:}

The author declared no prospective conflicts of the interest with respect to the research work.

\section{REFERENCES:}

1. Albert L. Blackwell (1999), The Sacred in Music, Kentucky, Westminster John Knox Press. Pp169-170.

2. Aleen Imran Iqbal (2018), The Music of Pakistan, Available at -

https://paktopia.wordpress.com/2018/04/05/the -music-of-pakistan/. Accessed 10/07/2020

3. Chaitannya Kunte, (2012). Folk music of India. Online, available at https://www.swarganga.org/articles/details.php ?id=11. Accessed 10/07/2020.

4. Cultural India, (2020). Available at https://www.culturalindia.net/indian-music/ folk-music.html. Accessed 10/07/2020.

5. David Courtney, (2020). Overview of Indian Folk Music. Available in https://chandrakantha.com/articles/indian_mus ic/folk_music.html. Accessed 10/07/2020.

6. Erin Banting (2003), Afghanistan: the culture, New York, Crabtree publishing company.

7. Hiromi Lorraine Sekata, (2012). Music of Afghanistan. Available at http://media.nationalgeographic.org/assets/file/ asia_3.pdf. Accessed 10/07/2020.

8. Hossain MK. (2020). Bhagabania, Nigamananda and Baha'i of Jashore in Bangladesh: A Study of Women, Asian J. Soc. Sci. Leg. Stud., 2(2), 41-46. https://doi.org/10.34104/ajssls.020.041046 
9. Jameela Siddiki (2019), An Introduction to Indian Folk Traditions: some important genres https://www.darbar.org/article/an-introductionto-indian-folk-traditions-some-importantgenres/81. Accessed 10/07/2020.

10. Marian Rengle (2004), Pakistan: A primary source cultural guide, New York. The Rosen Publishing group. https://saleemrazasblogs.blogspot.com/2014/0 5/music-of-pakistan.html. Accessed 10/07/2020.

11. Mridulkanti Chakraborty, (2011), Bangla ganer dhara: hajar bochorer bangla gan, Dhaka Papiras Publications. pp 5-20.

12. Prabhat kumer Goswami (2005), Varotiya sangeeter katha, Kolkata. Nath Publication. Pp 241-266.

https://shodhganga.inflibnet.ac.in/browse?type =author $\&$ value $=$ Goswami $\% 2 \mathrm{C}+$ Prabhat + Kum ar\&value_lang=
13. Richard M. Dorson (1972), Folklore and Folk life: A general discussion, Online available at https://shodhganga.inflibnet.ac.in/bitstream/10 603/194723/7/07 chapter\%201.pdf. Accessed 10/07/2020.

14. Rudolfo Sun Miguel (2018), Music of South Asia-Nepal, India, Maldives, Afghanistan. Available at https://gromaudio.com/blog/2018/08/musicsouth-asial. Accessed 10/07/2020.

15. Ruksana karim (2017), Bibartaner dharay Bangladesher cholocchitrer gan, Dhaka, Bangladesh film archive Press. P 60.

16. Saha KK. (2020). Dependency among Kautilya's three major ideas: Upaya, Sadgunya, and Prakrti, Br. J. Arts Humanit., 2(2), 24-35. https://doi.org/10.34104/bjah.020024035

17. Simon Broughton, Mark Ellingham, James MacConnachie, and Orla Duane (2000), World music: vol 2, London.

https://www.worldcat.org/title/world-musicthe-rough-guide/oclc/43586081

Citation: Karim R. (2020). Evolution and assessment of South Asian folk music: a study of social and religious perspective, Br. J. Arts Humanit., 2(3), 60-72. https://doi.org/10.34104/bjah.020060072 